This Accepted Author Manuscript is copyrighted and published by Elsevier. It is posted here by agreement between Elsevier and University of Brasilia. Changes resulting from the publishing process - such as editing, corrections, structural formatting, and other quality control mechanisms - may not be reflected in this version of the text. The definitive version of the text was subsequently published in [Tissue and Cell, Volume 31, Issue 3, June 1999, Pages 349-356, doi:10.1054/tice.1999.0035].You may download, copy and otherwise use the AAM for noncommercial purposes provided that your license is limited by the following restrictions:

(1) You may use this AAM for non-commercial purposes only under the terms of the CC-BY-NCND license.

(2) The integrity of the work and identification of the author, copyright owner, and publisher must be preserved in any copy.

(3) You must attribute this AAM in the following format: [agreed attribution language, including link to CC BY-NC-ND license + Digital Object Identifier link to the published journal article on Elsevier's ScienceDirect ${ }^{\circledR}$ platform].

Este Manuscrito do Autor Aceito para Publicação (AAM) é protegido por direitos autorais e publicado pela Elsevier. Ele esta disponível neste Repositório, por acordo entre a Elsevier e a Universidade de Brasília. As alterações decorrentes do processo de publicação - como a edição, correção, formatação estrutural, e outros mecanismos de controle de qualidade - não estão refletidas nesta versão do texto. A versão definitiva do texto foi posteriormente publicado em [Tissue and Cell, Volume 31, Número 3, Junho de 1999, Páginas 349-356, doi:10.1054/tice.1999.0035]. Você pode baixar, copiar e utilizar de outra forma o AAM para fins não comerciais , desde que sua licença seja limitada pelas seguintes restrições:

(1) Você pode usar este AAM para fins não comerciais apenas sob os termos da licença CC- BYNC-ND.

(2) A integridade do trabalho e identificação do autor, detentor dos direitos autorais e editor deve ser preservado em qualquer cópia.

(3) Tem de atribuir este AAM no seguinte formato: [acordo na linguagem atribuída, incluindo o link para CC BY-NC-ND licença Digital + DOI do artigo publicado na revista Elsevier ScienceDirect ${ }^{\circledR}$ da plataforma]. 


\title{
Ultrastructural localization of enzymatic activity during spermiogenesis in two phytophagous bugs (Hemiptera: Pentatomidae)
}

\author{
A.P. Fernandes \\ S. N. Báo
}

\begin{abstract}
Ultrastructural cytochemical techniques were used for the localization of phosphatases and oxidases in spermatid and spermatozoon of the phytophagous bugs Acrosternum aseadum and Nezara viridula (Hemiptera: Pentatomidae). Acid phosphatase was found mainly in the trans most portion of the Golgi complex, and in the acrosome of spermatozoon. Glucose-6phosphatase was located in the endoplasmic reticulum, trans portion of the Golgi complex and in the acrosome of spermatids. The axoneme showed activity of acid phosphatase, glucose-6phosphatase and thiamine pyrophosphatase. This observation supports the idea that various phosphates may play some role in spermatid differentiation. Indeed, the presence of cytochrome oxidase activity was only shown in the mitochondrial cristae of early spermatids, suggesting also the participation of this enzyme during spermatid differentiation of this insect.
\end{abstract}

Keywords: Acrosternum aseadum, cytochemistry, cytochrome C oxidase, insects, Nezara viridula, phosphatases

\section{Introduction}

The spermatozoon is the result of a complex process of cellular differentiation. During this process, morphofunctional modifications occur based on biochemical and cytochemical changes (Phillips, 1970; Baccetti, 1972; Fawcett, 1975). The constructive and regressive cellular alterations occurring during spermiogenesis provide spermatozoa capable of reaching and fertilizing immotile oocyte. These morphogenetic changes involve sequestration and condensation of genetic and energetic material and elimination of nuclear and cytoplasmic components non essential to fertilization (André, 1963; Anderson et al., 1967).

This phenomenon involves the participation of several enzymes, including phosphatases. Acid phosphatase is a hydrolase which participates in the metabolism of phosphate. This enzyme has been localized in proacrosomal vesicles (Anderson, 1968; Souza et al., 1988; ThorneTjolmsland et al., 1988; Báo et al., 1989; Furtado \& Báo, 1996), on the axoneme (Anderson et al., 1968; Bigliardi et al., 1970; Baccetti et al., 1971; Beaulaton \& PerrinWaldemar, 1973; Báo \& Dolder, 1990; Báo, 1991; 1996; 1998; Báo \& de Souza, 1994) and plasma membrane (Anderson et al., 1968; Báo \& de Souza, 1994). Thiamine pyrophosphatase activity has been detected in the plasma membrane of insect (Baccetti, 1977; Báo \& de Souza, 1994) and mollusc sperm cells (Anderson et al., 1968), as well as in the Golgi complex and axoneme of some invertebrates (Yasuzumi \& Lee, 1966; Báo \& de Souza, 1994; Furtado \& Báo, 1996). In addition, glucose-6-phosphatase activity has been shown in the endoplasmic 
reticulum and Golgi complex of rat (Thorne- Tjolmsland et al., 1991) and insects spermatids (Báo \& de Souza, 1994; Furtado \& Báo, 1996) and in the axoneme and mitochondrial compartments of spermatozoa of some invertebrate and vertebrate species (Anderson \& Personne, 1970; Bigliardi et al., 1970). The existence of such enzymatic activity to cytochrome $\mathrm{C}$ oxidase in the mitochondrial derivatives has been previously described in insects (Anderson \& Personne, 1970; Bigliardi et al., 1970; Baccetti et al., 1973; Báo et al., 1992).

The cytochemical study is useful to determine the functional role of different elements of the spermatozoon in its movement and in the fertilization process, and particularly to detect the role of enzymes in sperm development. The present paper analyses the localization of acid phosphatase, cytochrome $C$ oxidase, glucose-6-phosphatase and thiamine pyrophosphatase during spermiogenesis of Acrosternum aseadum and Nezara viridula which are pests of economically important crops throughout the world.

\section{Materials and methods}

The insects utilized were male adults of the phytophagous bugs Acrosternum aseadum and Nezara viridula (Hemiptera: Pentatomidae), obtained from a colony maintained in the National Center of Genetic Resource (CENARGEN), Brasília-Brazil.

\section{Enzyme cytochemistry}

The testes were dissected and briefly fixed for $15 \mathrm{~min}$ at $4^{\circ} \mathrm{C}$ in $1 \%$ glutaraldehyde buffered with $0.1 \mathrm{M}$ sodium cacodylate buffer, $\mathrm{pH}$ 7.2. After fixation, the specimens were washed with buffer and used for the cytochemical experiments.

\section{Acid phosphatase activity}

The fixed-washed testes were incubated for $1 \mathrm{~h}$ at $37^{\circ} \mathrm{C}$ in the following medium: $0.1 \mathrm{M}$ Trismaleate buffer, $\mathrm{pH} 5.0,7 \mathrm{mM}$ cytidine-5' -monophosphate, $2 \mathrm{mM}$ cerium chloride and 5\% sucrose (Pino et al., 1981). For controls, the substrate was omitted.

\section{Glucose-6-phosphatase activity}

The fixed-washed testes were incubated for $1 \mathrm{~h}$ at $37^{\circ} \mathrm{C}$ in the following medium: 5 $\mathrm{mM}$ glucose-6-phosphate, $5 \mathrm{mM}$ manganese chloride, $4 \mathrm{mM}$ cerium chloride, $5 \%$ sucrose and 0.1 M Tris-maleate buffer, pH 6.5 (Robinson \& Karnovsky, 1983). The controls were incubated in the same medium from which the substrate was omitted. 


\section{Thiamine pyrophosphatase activity}

The fixed-washed testes were incubated for $1 \mathrm{~h}$ at $37^{\circ} \mathrm{C}$ in the following medium: 2.2 $\mathrm{mM}$ thiamine pyrophosphate, $5 \mathrm{mM}$ manganese chloride, $4 \mathrm{mM}$ cerium chloride, $5 \%$ sucrose and $0.1 \mathrm{M}$ Tris-maleate buffer, pH 7.2 (Angermuller \& Fahimi, 1984). The controls were incubated in the same medium from which the substrate was omitted.

\section{Cytochrome C oxidase activity}

The fixed-washed testes were incubated for $1 \mathrm{~h}$ at $37^{\circ} \mathrm{C}$ in medium $3 \mathrm{mM} 3.3^{\prime}-$ diaminobenzidine tetrahydrochloride (DAB) (Sigma), $10 \mathrm{mM}$ cytochrome C (Sigma), and 5\% sucrose in $0.1 \mathrm{M}$ phosphate buffer, pH 7.2 (Seligman et al., 1968). In control preparations, cytochrome $\mathrm{C}$ was omitted.

After incubation of the testes in one of the media as described above, the specimens were washed with cacodylate buffer and fixed again for $3 \mathrm{~h}$ at $4^{\circ} \mathrm{C}$ in a solution containing $4 \%$ paraformaldehyde, $2 \%$ glutaraldehyde in $0.1 \mathrm{M}$ sodium cacodylate buffer, $\mathrm{pH}$ 7.2. The specimens were then washed in clean buffer, and postfixed in a solution containing $1 \%$ osmium tetroxide, $0.8 \%$ potassium ferricyanide and $5 \mathrm{mM}$ calcium chloride in $0.1 \mathrm{M}$ sodium cacodylate buffer. Subsequently, they were dehydrated in acetone and embedded in Spurr. Thin sections were stained with uranyl acetate and lead citrate, and examined in a Jeol JEM $100 \mathrm{C}$ or in a Zeiss 912 transmission electron microscope.

\section{Results}

The general structure of the spermatids in Acrosternum aseadum and Nezara viridula by transmission electron microscopy has been described in detail previously (Fernandes \& Báo, 1998a). The spermatids undergo a series of modifications, resulting in the formation of a highly differentiated cell, the spermatozoon, which consists of two anatomically and functionally distinct regions: a head, containing the nucleus and the acrosome, and the tail, which is formed by an axoneme and two mitochondrial derivatives, containing two paracrystalline structures. 


\section{Acid phosphatase activity}

Incubation of spermatids in a medium containing cytidine- 5'- monophosphate as substrate, and cerium as capture agent, led to the appearance of an electron-dense reaction product, indicating the presence of acid phosphatase activity. The reaction product was seen in association with the Golgi complex, in the trans-most region and trans Golgi network of early spermatids (Fig. 1). However, no reaction product was observed in the proacrosomal granule (Fig. 1), although it has been shown that the Golgi complex participates actively in the formation of acrosome. On the intermediated phase of spermiogenesis the reaction product was uniformly distributed on the acrosome (Fig. 2). In the final stages, the reaction product was observed mainly on the posterior region of acrosome, with some electron dense precipitated on the acrosomal membrane and acrosome content (Fig. 3).

Deposition of reaction product was localized specifically in the spermatid and spermatozoon axoneme (Figs 4-6). In spermatids, a light deposition of reaction product was observed (Fig. 4), and in the spermatozoon, marked deposition was observed on the axoneme (Figs 5 \& 6). The reaction product was also observed in the crystae of mitochondrial derivative (Fig. 6).

\section{Glucose-6-phosphatase activity}

Following incubation of the spermatids in a medium containing glucose-6-phosphate as substrate and cerium chloride as capture agent, reaction product was seen in association with the endoplasmic reticulum in early spermatids (Fig. 7). In the next stage, reaction product was seen in association with Golgi complex, in the trans region and trans Golgi network, as well as on some vesicles from the Golgi complex (Fig. 8). A light labeling was observed on the acrosome of late spermatids, mainly over the acrosomal membrane (Fig. 9).

A diffuse weak reaction was observed on the membrane of the nebenkern of spermatids (Fig. 10). Reaction product was observed on the axoneme of spermatozoa, in the radial spokes that extend from the central pair of microtubules towards the nine microtubule doublets, as well as around the accessory microtubules (Fig. 11). 


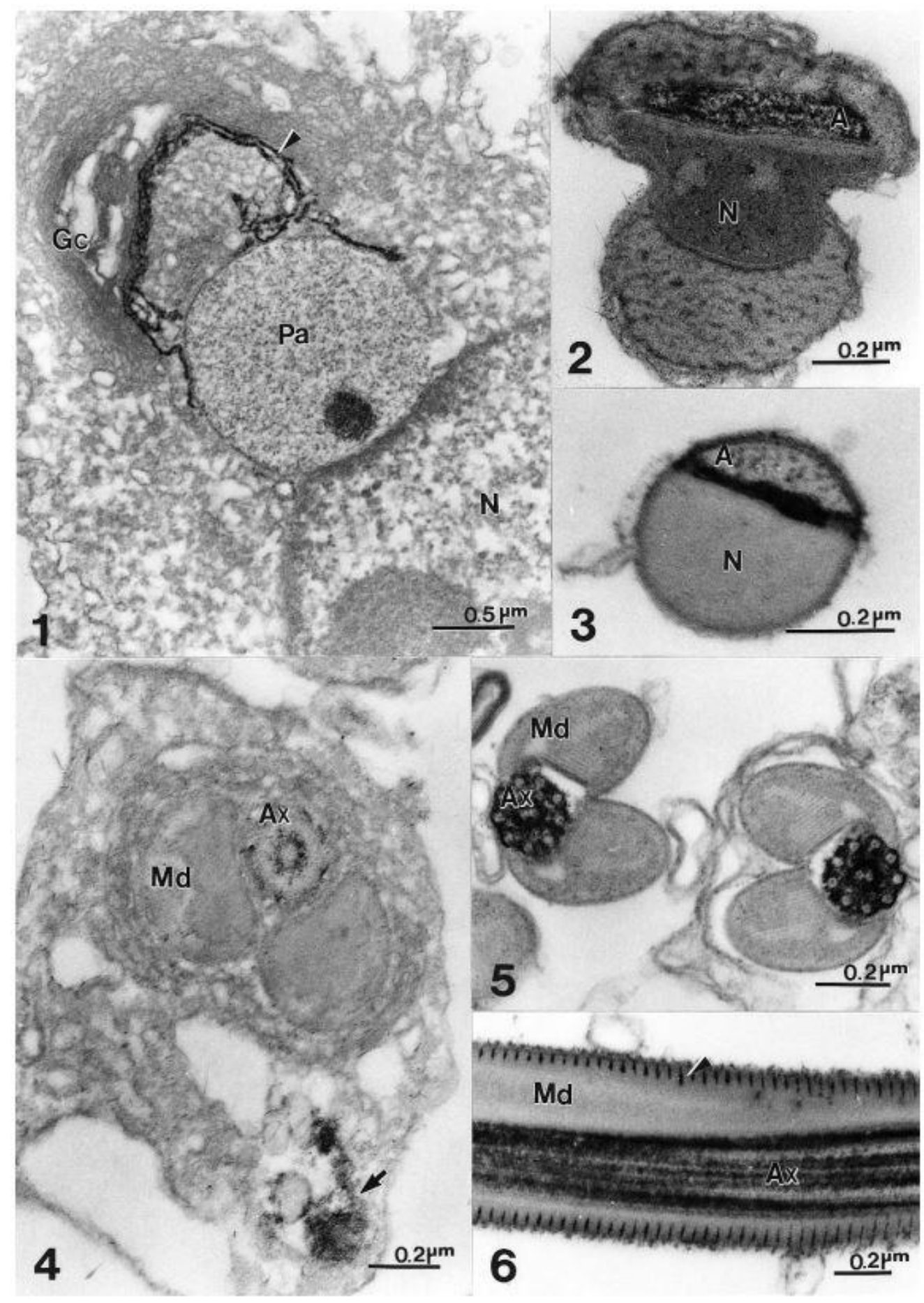

Figs 1-3 Localization of acid phosphatase activity. Fig. 1 The reaction product is associated with trans Golgi and trans Golgi network (arrowhead) on N. viridula spermatids. Gc, Golgi complex; N, nucleus; Pa, proacrosomal granule. $X 30000$. Fig. 2 Thin section of $N$. viridula spermatid showing the reaction product in the acrosome (A); N, nucleus. X 69 000. Fig. 3 Transverse section through $A$. aseadum spermatozoon head. The reaction product was observed mainly on the posterior region of acrosome (A) $\mathrm{N}$, nucleus. X 101 000. Figs 4-6 Localization of acid phosphatase in the flagellar region of $N$. viridula spermatid Fig. 4 Transverse section on spermatid flagellum showing reaction product on the axoneme $(\mathrm{Ax})$; and in a digestive vacuole (arrow). Md, mitochondrial derivatives. X 68 000. Fig. 5 Transverse section of spermatozoa flagellum showing strong reaction on the axoneme ( $\mathrm{Ax}$ ). $\mathrm{Md}$, mitochondrial derivatives. X 69 000. Fig. 6 Longitudinal section through flagellum spermatozoon showing the reaction product in the axoneme ( $\mathrm{Ax}$ ), and in the mitochondrial derivatives (Md) crystae (arrowhead). X 56000. 


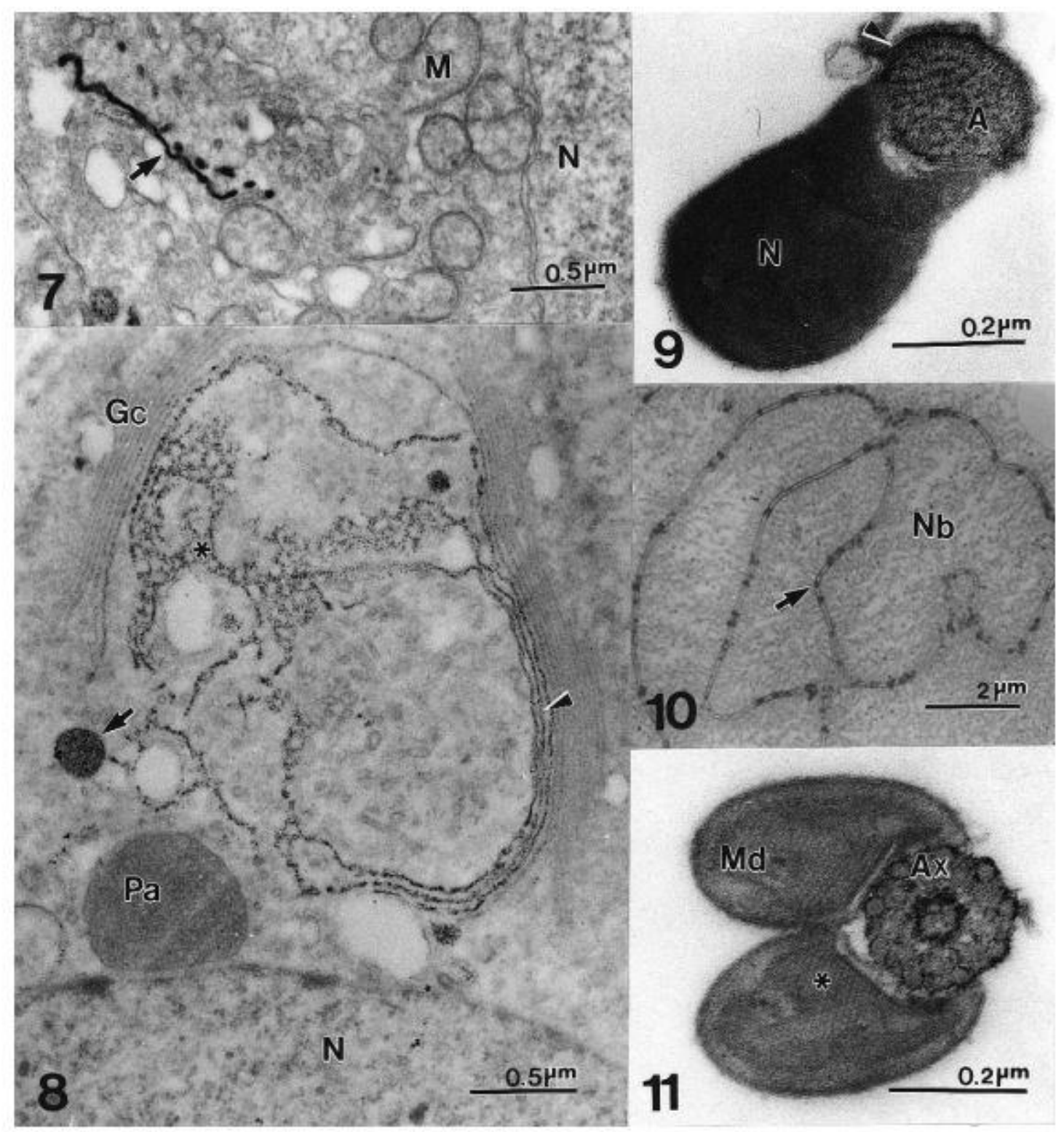

Figs 7-11 Localization of glucose-6-phosphatase activity. Fig. 7 Early spermatid of A. aseadum showing the reaction product on the endoplasmic reticulum (arrow). M, mitochondria; N, nucleus. X 30000 . Fig. 8 Spermatid of $A$. aseadum showing reaction product on the trans Golgi (arrowhead), trans Golgi network $\left({ }^{*}\right)$, and some vesicles (arrow) from the Golgi complex (Gc). N, nucleus; Pa, proacrosomal granule. X 35 000. Fig. 9 Transverse section through head region of $N$. viridula spermatid in final stage of differentiation. Reaction product can be seen in the acrosome (A), and acrosomal membrane (arrowhead). N, nucleus. X 108 000. Fig. 10 Initial stage of A. aseadum spermatid differentiation. Reaction product can be seen in membrane (arrowhead) of nebenkern (Nb). X 7500. Fig. 11 Transverse section through $\mathrm{N}$. viridula spermatozoon flagellum. The reaction product was observed on the axoneme $(\mathrm{Ax})$. The mitochondrial derivatives $(\mathrm{Md})$ are formed by paracrystalline structures $\left({ }^{*}\right) . \mathrm{X} 110$ 000 .

\section{Thiamine pyrophosphatase activity}

After incubating the spermatids in a medium containing thiamine pyrophosphate as substrate, and cerium as capture agent, no reaction product was found in the Golgi complex of 
early spermatids (Fig. 12), indeed no reaction product was observed on the acrosome of spermatids on the intermediated phases of differentiation (Fig. 13).

Reaction product indicative of thiamine pyrophosphatase activity was seen in the endoplasmic reticulum cisternae surrounding the axoneme and the tail elements (Fig. 14). This reaction product was also observed on the paracrystalline structure of the mitochondrial derivatives of spermatids (Fig. 14) and spermatozoon (Fig. 15), as well as on the axoneme of spermatozoon, mainly around the central pair of microtubules and around the accessory microtubules (Fig. 15).

\section{Cytochrome C oxidase activity}

After incubation in a medium with cytochrome $\mathrm{C}$ as substrate and diaminobenzidine tetrahydrochloride (DAB) as capture agent, the cytochrome $\mathrm{C}$ oxidase activity was evidenced in mitochondrial cristae of early spermatids (Figs $16 \& 17$ ). However, this reaction product was not seen in the paracrystalline structures or in the last stages of sperm maturation process (Fig. 18). In all cases, omission of the substrates from the incubation medium abolished the appearance of reaction product (not shown).

\section{Discussion}

The spermiogenesis process involves the structural and physiological transformation of organelles to more adapted forms, at the fertilization process. These changes involve transient establishment of cytoplasmic compartments related to cell elongation and cytoplasmic elimination. Hence, during spermiogenesis, only components essential to fertilization are preserved and all other components are discarded (Andre, 1963; Anderson et al., 1967). Several enzymes may be involved in this remodeling, as well as in the chemical changes which occur during this process.

During the early phase of spermiogenesis, in A. aseadum and N. viridula, the Golgi apparatus contributes with material to the developing acrosomic system, similarly to what occurs in other insects (Báo et al., 1989; Ndiaye \& Mattei, 1992; Báo \& de Souza, 1994; Fernandes \& Báo, 1998b). Our observations show that acid phosphatase can be detected cytochemically in the Golgi complex, acrosome and axoneme. The acid phosphatase activity has been associated with the Golgi because, by definition, the trans Golgi network is the site where proteins finally exit from the Golgi to their respective cellular sites (Griffiths \& Simons, 1986; Grab et al., 1997), i.e. plasma membranes, secretion granules and lysosomes. In germinal cells, the presence of acid phosphatase has been mainly related to the acrosome 
(Anderson, 1968; Allison \& Hartree, 1970; Souza et al., 1988; Báo et al., 1989) and the axoneme (Anderson et al., 1968; Bigliardi et al., 1970; Baccetti et al., 1971; Beaulaton \& PerrinWaldemar, 1973; Báo \& Dolder, 1990; Báo, 1991; 1996; 1998; Báo \& de Souza, 1994).

In the proacrosomal vesicle of $A$. aseadum and $\mathrm{N}$. viridula the reaction product of acid phosphatase is entirely absent. As this vesicle condenses and attaches itself to the nucleus, the reaction product of this reaction increases. In the mature spermatozoa the reaction product is redistributed and the posterior region of acrosome exhibits a heavy concentration of precipitate. Thus, during acrosome maturation, the response to the acid phosphatase reaction is considerably modified and seems to vary among species (Báo et al., 1989; Anderson, 1968; Souza \& Azevedo, 1986; Furtado \& Báo, 1996).

The region of the axoneme where acid phosphatase activity was detected corresponds to those described for the spermatozoa of other insects (Anderson et al., 1968; Bigliardi et al., 1970; Baccetti et al., 1971; 1973; Beaulaton \& Perrin-Waldemar, 1973; Báo \& Dolder, 1990; Báo, 1991; 1996; 1998; Báo \& de Souza, 1994). This enzymatic activity is present only after the axoneme has acquired all its microtubules and interconnecting fibres, and is fully equipped for movement. Thus, acid phosphatase might be involved in the metabolism of phosphate compounds important to flagellar motility. Acting strictly as a hydrolase it could regulate the content of hydrolyzable substrate and the equilibrium and activities of other enzymes in the axial filament. The reaction product of acid phosphatase present on the mitochondria derivative crystae could be an enzymatic activity or deposits due non integrity of membrane plasmatic.

In the present study, in spermatids, endoplasmic reticulum cisternae displayed glucose-6-phosphatase activity. This observation confirms the association of this enzymatic activity with the endoplasmic reticulum in germinal cells (Thorne-Tjomsland et al., 1991; Báo \& de Souza, 1994; Furtado \& Báo, 1996). In Acrosternum and Nezara spermatids glucose-6phosphatase it is not restricted to the endoplasmic reticulum as in hepatocytes (Farquhar et al., 1974). It is present in the Golgi complex, mainly on the trans region and trans Golgi network, as well as in vesicles that bud from the Golgi complex. These results suggest an important role of this enzyme during acrosome formation. This enzyme is detected also on the acrosome, which is rich in hydrolases, as well as on the nebenkern of spermatid and on the axoneme of spermatozoon. The presence of glucose- 6-phosphatase in spermatids and spermatozoa indicates the presence of glycogenolytic pathways. 


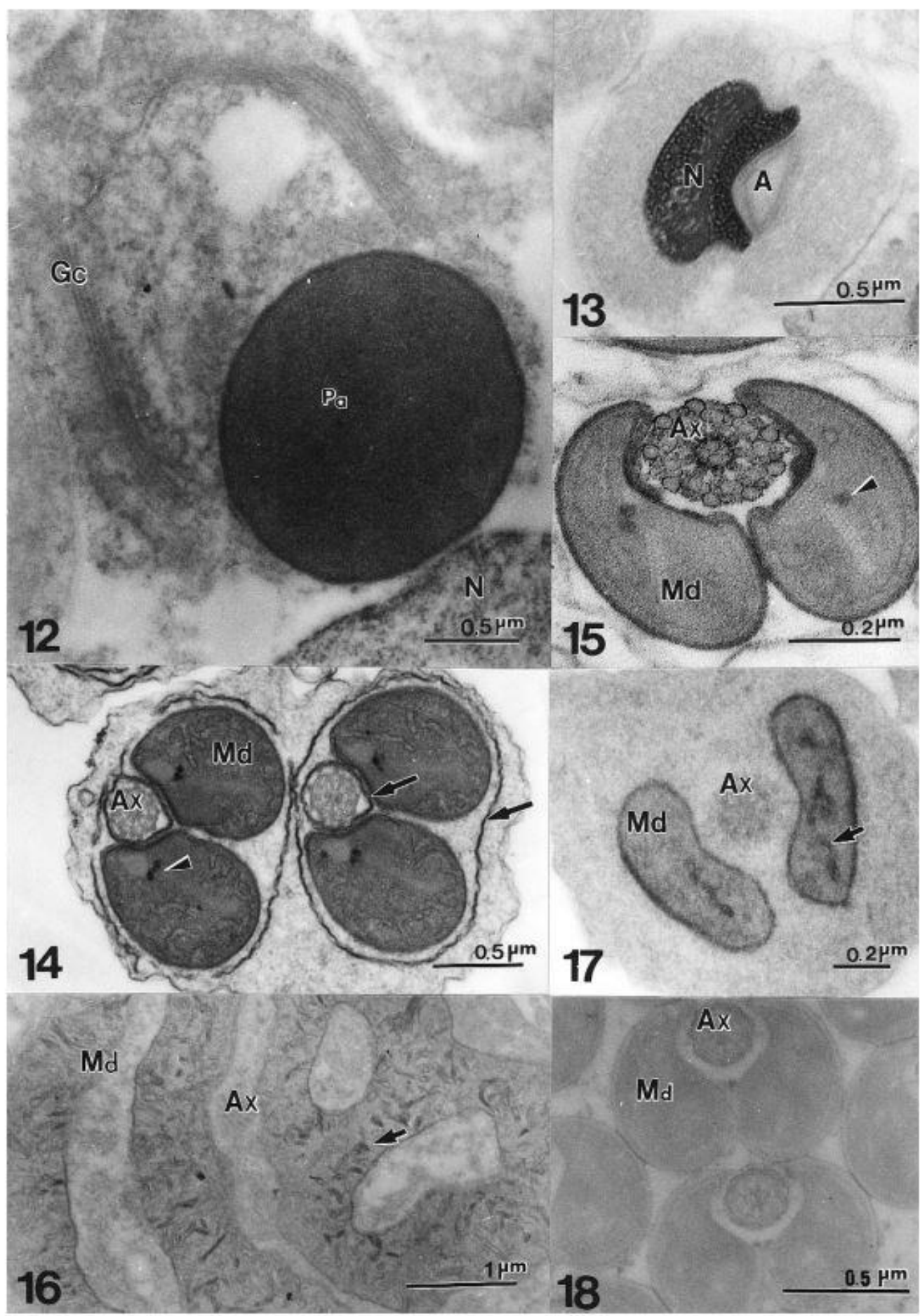

Figs 12-15 Localization of thiamine pyrophosphatase in A. aseadum spermatids. Fig. 12 Initial stage of spermatid differentiation. Neither reaction product was observed on the Golgi complex (Gc) as well as in proacrosomal granule (Pa). N, nucleus. X 34 000. Fig. 13 Transverse section through head spermatids. Neither reaction product was observed on the acrosome (A). N, nucleus. X 48 000. Figs 14 \& 15 Transverse section through flagellar region, showing reaction product on the axoneme $(\mathrm{Ax})$ of the spermatozoon and on the paracrystalline structures (arrowhead) in the mitochondrial derivatives (Md) of spermatids and spermatozoon. Reaction product was also observed in the endoplasmic reticulum (arrows). X 32 000; X 104 000, respectively. Figs 16-18 Localization of Cytochrome C oxidase. Figs 16 \& 17 Section through $N$. viridula spermatid on the flagellar region. Reaction product was observed on the cristae (arrow) of mitochondrial derivatives (Md) of early spermatids. Ax, axoneme. X $21000 ;$ X 52 000, respectively. Fig. 18 No reaction product is observed in $A$. aseadum spermatids in late stages of differentiation. Ax, axoneme; Md, mitochondrial derivatives 
Thiamine pyrophosphatase is generally considered to be a cytochemical marker for the trans side of the Golgi complex in many cell types (Cheetham et al., 1971; Angermuller \& Fahimi, 1984; Roth et al., 1985). However, in Acrosternum and Nezara spermatids, it was not possible to detect this enzyme on the Golgi complex or in the acrosome, but this enzymatic activity is present in the endoplasmic reticulum cisternae. Thiamine pyrophosphatase can serve as an enzyme to monitor the process of glycosilation and is an important indicator of cellular metabolic activity (Thomopoulos et al., 1992). The presence of thiamine pyrophosphatase on paracrystalline structures of the mitochondrial derivatives, in several stages of spermatid differentiation, indicated a possible participation of this enzyme in the pyruvate metabolism. Previous studies have shown that thiamine pyrophosphatase is necessary for the oxidative phosphorylation of pyruvate (Anderson et al., 1968). Consequently, its consistent appearance on mitochondrial crystal suggest that this enzyme has a metabolic role in mitochondrial derivatives as well as in the axoneme of spermatozoon, which presents a metabolic activity related to flagellar movement.

The changes that take place in the mitochondria during spermatid differentiation lead to the appearance of a distinct compartment in the mitochondria of the insect sperm. The paracrystalline organization may result from the reorganization of the mitochondrial cristae proteins. Our observations show the presence of cytochrome $\mathrm{C}$ oxidase activity only in mitochondrial cristae. In insect sperm, the paracrystalline structure does not seem to have cytochrome C oxidase activity as is usually found in mitochondrial cristae (Bigliardi et al., 1970; Baccetti et al., 1973; Perotti, 1973). However, this enzymatic activity has been previously described in the amorphous material and membrane complexes that surround the paracrystalline structure in mosquito spermatozoon (Báo et al., 1992). This result indicates that the activity of cytochrome $\mathrm{C}$ oxidase occurs mainly in the early phase of spermatid differentiation and that this enzyme is not essential for the final stages of differentiation, or for the flagellum movement (Baccetti et al., 1973).

In situ detection of enzymes activities contributes to the understanding of their biological role in vivo by relating function to localization in subcellular compartments. Thus, acid phosphatase, glucose-6-phosphatase, thiamine pyrophosphatase and cytochrome $\mathrm{C}$ oxidase might be involved in spermatid remodeling, as well as in the chemical changes which occur in spermatids during spermiogenesis. Further studies are necessary to elucidate their role. 


\section{ACKNOWLEDGEMENTS}

We thank Dr M. Borges for supplying the insects and Centro Nacional de Recursos Genéticos (CENARGEN) for the use of transmission electron microscopy. This work was supported by Coordenação de Aperfeiçoamento de Pessoal de nível Superior (CAPES), Conselho Nacional de Desenvolvimento Científico e Tecnológico (CNPq), Fundação de Amparo a Pesquisa do Distrito Federal (FAPDF) and Programa de Apoio de Núcleos de Excelência (Pronex).

\section{REFERENCES}

Allison, A.C. and Hartree, E.F. 1970. Lysosomal enzymes in the acrosome and their possible role in fertilization. J. Reprod. Fert., 21, 501-515.

Anderson, W.A. 1968. Cytochemistry of sea gametes. III. Acid and alkaline phosphatase activity of spermatozoa and fertilization. J. Ultrastruct. Res., 25, 1-14.

Anderson, W.A. and Personne, P. 1970. Recent cytochemical studies on spermatozoa of some invertebrate and vertebrate species. In: Baccetti, B. (ed) Comparative Spermatology. Accademia Nazional dei Lincei, Rome, 431-450.

Anderson, W.A., Weissman, A. and Ellis, R.A. 1967. Cytodifferentiation during spermiogenesis in Lumbricus terrestris. J. Cell Biol., 32, 11-26.

Anderson, W.A., Personne, P. and André, J. 1968. Chemical compartimentalization in Helix spermatozoa. J. Microsc., 7, 367-390.

André J. 1963. Some aspects of specialization in sperm. In: Mazia, D. and Tyler, A. (eds) General Physiology of cell specialization. McGrawHill, New York, 91-115.

Angermuller, S.L. and Fahimi, D.H. 1984. A new cerium-based method for cytochemical localization of thiaminepyrophosphatase in the golgi complex of rat hepatocytes.

Histochemistry, 80, 107-11.

Baccetti, B. 1972. Insect sperm cells. Adv. Insect Physiol., 9, 315-397.

Baccetti, B. 1977. Unusual feature of insect spermatogenesis. In: Brinkley, B.R. and Porter, K.R. (eds) International Cell Biology. Rockfeller University Press, USA, 580-587.

Baccetti, B., Bigliardi, E., Burrini, A.G. and Rosati, F. 1971. Histochemical observation on the insect sperm cell by electron microscope. J. Ultrastruct. Res., 37, 248-249.

Baccetti, B., Burrini, A.G., Dallai, R. et al. 1973. Structure and function in the spermatozoon of Tenebrio molitor (The spermatozoon of Arthropoda, XX). J. Mechanochem. Cell Motil., 2, 149161.

Báo, S.N. 1991. Morphogenesis of the flagellum in the spermatids of Coelomera lanio (Coleoptera, Chrysomelidae): ultrastructural and cytochemical studies. Cytobios, 66, 157-167. 
Báo, S.N. 1996. Spermiogenesis in Coelomera lanio (Chrysomelidae: Galerucinae): ultrastructural and cytochemical studies. In: Jolivet P.H.A. and Cox M.L. (eds) Chrysomelidae Biology General Studies. SPB Academic Publishing, Amsterdam, vol. 3, 119-132.

Báo, S.N. 1998. Ultrastructural and cytochemical studies on spermiogenesis of the beetle Cerotoma arcuata (Coleoptera, Chrysomelidae). BioCell, 22, 35-44.

Báo, S.N. and de Souza, W. 1994. Cytochemical localization of enzymes in the spermatid and the spermatozoon of Culex quinquefasciatus Say (Diptera, Culicidae). J. Insect Morphol.Embryol., 23, 57-67.

Báo, S.N. and Dolder, H. 1990. Ultrastructural localization of acid phosphatase in spermatic cells of Ceratitis capitata (Diptera). Histochemistry, 93, 439-442.

Báo, S.N., Lins, U., Farina, M. and de Souza, W. 1992. Mitochondrial derivatives of Culex quinquefasciatus (Culicidae) spermatozoon: some new aspects evidenced by cytochemistry and image processing. J. Struct. Biol., 109, 46-51.

Báo, S.N., Quaggio-Grassiotto, I. and Dolder, H. 1989. Acrosome formation in Ceratitis capitata (Diptera, Tephritidae). Cytobios, 58, 93-100.

Beaulaton, J. and Perrin-Waldemar, C. 1973. Localisation ultrastructural d'une activité phosphatasique acide dans les spermatids et les spermatozoids de Drosophila melanogaster. C.R. Acad. Sci. (Paris), 276, 2277-2280.

Bigliardi, E., Baccetti, B., Burrini, A.G. and Pallini, V. 1970. The spermatozoon of arthropoda. XIII. The distribution of some enzymes in the insect sperm tail. In: Baccetti, B. (ed) Compartive Spermatology Accademia Nazionale dei Lincei, Rome, 451-463.

Cheetham, R.D., Morré, J.D., Pannek, C. and Friend, D.S. 1971. Isolation of a Golgi apparatus rich fraction from rat liver. IV. Thiamine pyrophosphatase. J. Cell Biol., 49, 899-905.

Farquhar, M.G., Bergeron, J.J.M. and Palade, G.E. 1974. Cytochemistry of Golgi fractions prepared from rat liver. J. Cell Biol., 60, 8-25.

Fawcett, D.W. 1975. The mammalian spermatozoon. Dev. Biol., 44, 394-436.

Fernandes, A.P. and Báo, S.N. 1998a. Spermiogenesis in phytophagous bug (Hemiptera, Pentatomidae): an ultrastructural study. J. Submicrosc. Cytol. Pathol., 30, 485-493.

Fernandes, A.P. and Báo, S.N. 1998b. Contribution of the Golgi complexendoplasmic reticulum system during spermiogenesis in three species of phytophagous bugs (Hemiptera:

Pentatomidae). Int. J. Insect Morphol. Embryol., 27, 235-240.

Furtado, D.A. and Báo, S.N. 1996. Ultrastructural localization of phosphatases in sperm cells of the beetle Diabrotica speciosa (Coleoptera, Chrysomelidae). Cytobios, 88, 83-93.

Grab, D.J., Webster, P., Verjee, Y. and Lonsdale-Eccles, J. 1997. Golgiassociated phosphohydrolases in Trypanosoma brucei brucei. Mol. Biochem Parasit., 86, 127-132. 
Griffiths, G. and Simons, K. 1986. The trans Golgi network: sorting at exit site of the Golgi complex. Science, 234, 438-443.

Ndiaye, M. and Mattei, X. 1992. Particularity of acrosome formation during spermiogenesis in two mosquitoes: Toxorhynchites brevipalpis and Anopheles gambiae. J. Submicrosc. Cytol.

Pathol., 24, 269-272.

Perotti, M.G. 1973. The mitochondrial derivative of the Spermatozoon of Drosophila before and after fertilization. J. Ultrastruct. Res., 44, 181-198.

Phillips, D.M. 1970. Insect sperm: their structure and morphogenesis. J. Cell Biol., 44, 243-277.

Pino, R.M., Pino, L.C. and Bankston, P.W. 1981. The relationship between the Golgi apparatus, GERL, and lysosomes of fetal rat liver kupffer cells examined by ultrastructural phosphatase cytochemistry. J. Histochem. Cytochem., 29, 1060-1070.

Robinson, J.M. and Karnovsky, M.J. 1983. Ultrastructural localization of several phosphatases with cerium. J. Histochem. Cytochem., 31, 1197-1208.

Roth, J., Taatjes, D.J., Lucocq, J.M., Weinstaein, J. and Paulson, J.C. 1985. Demonstration of an extensive trans-tubular network continuous with the Golgi apparatus stack that may function in glycosylation. Cell, 43, 287-295.

Seligman, A.M., Karnovsky, M.J., Wasswekrug, H.L. and Hanker, J.S. 1968. Nondroplet ultrastructural demonstration of cytochrome oxidase activity with a polymerizing osmiophilic reagent, diaminobenzidine (DAB). J. Cell Biol., 38, 1-14.

Souza, M. and Azevedo, C. 1986. Cytochemical study on the spermatozoon and at early fertilization in Marthasterias glacialis (Echinodermata, Asteroidea). Biol. Cell, 56, 79-84.

Souza, M., Moradas Ferreira, P., Amorin, A. and Azevedo, C. 1988.

Starfish acrosomal acid phosphatase: a cytochemical and biochemical study. Biol. Cell, 63, 101104.

Thomopoulos, G.N., Neophytou, E.P., Alexiou, M., Vadolas, A., LimberiThomopoulos, S. and Derventzi, A. 1992. Structural and histochemical studies of Golgi complex differentiation in salivary gland cells during Drosophila development. J. Cell Sci., 102, 169-184.

Thorne-Tjolmsland, G., Clermont, Y. and Hermo, L. 1988. Contribution of the Golgi apparatus components to the formation of the acrosomic system and chromatoid body in rat spermatids. Anat. Rec., 221, 591-598.

Thorne-Tjolmsland, G. Clermont, Y. and Tang, X. 1991. Glucose-6-phosphatase activity of endoplasmic reticulum and Golgi apparatus in spermatocytes and spermatids of the rat: an electronic microscopic cytochemical study. Biol. Cell, 71, 33-41.

Yasuzumi, G. and Lee, K.J. 1966. Spermatogenesis in animals as revealed by electron microscopy. VI. The microtubular structure and sites of thiamine pyrophosphatase activity in premature sperm of the Japanese crayfish. Z. Zellforsch., 73, 384-404 